IP Periodica Polytechnica Chemical Engineering

62(2), pp. 188-194, 2018

https://doi.org/10.3311/PPch.10354

Creative Commons Attribution (i)

RESEARCH ARTICLE

\section{Bipolar Packed-bed Electrochemical Reactor for the Degradation of Diclofenac; a Bio-refractory Organic Compound}

\author{
Carlos Carlesi ${ }^{1 *}$, Nadia Guajardo ${ }^{2}$, Alessandro Monteverde Videla ${ }^{3}$, \\ Jaime Morales $^{1}$, Álvaro Aracena ${ }^{1}$
}

Received 04 December 2016; accepted after revision 13 March 2017

\begin{abstract}
Pharmaceuticals have low biodegradability and can retain their chemical structure for long periods of time leading to an accumulation in the environment causing irreversible changes. Electrochemical oxidation has been proved to be an environmentally friendly and economically viable solution for biorefractory of organic molecules as well as for the disinfection of wastewaters. This paper aims to evaluate the performance of specific energy consumption for a given reduction of toxic organic compound loads in a continuous flow bipolar packedbed electrochemical reactor and compare this with a classical parallel plate reactor. The energy cost for both the parallel plate and bipolar electrochemical reactors are similar (around $1.6 \mathrm{kWh} \mathrm{m}^{-3}$ ) lower than other advanced oxidation process reported in literature. However, the bipolar configuration is particularly suitable for low conductivity waste water and/or for avoiding the formation of organochloride compounds in a chloride rich wastewater.
\end{abstract}

\section{Keywords}

electroxidation, advanced oxidation process, tin oxide electrode, pharmaceutical compounds, bipolar electrochemical reactor, Diclofenac

${ }^{1}$ Escuela de Ingeniería Química,

Pontificia Universidad Católica de Valparaíso,

Avda. Brasil 2162, Valparaíso, 2362854, Chile

${ }^{2}$ Centro de Desarrollo y Transferencia Tecnológica (CEDYTEC), Facultad de Ingeniería, Ciencia y Tecnología, Universidad Bernardo O’Higgins,

Avda. Viel 1497, Santiago, Chile

${ }^{3}$ Department of Applied Science and Technology,

Politecnico di Torino,

Corso Duca degli Abruzzi 24, Turin, 10129, Italy

*Corresponding author, e-mail: carlos.carlesi@pucv.cl

\section{Introduction}

Dissolved organic contaminants present in municipal wastewater are usually controlled by processes based on secondary biological treatment. These well-stated techniques are often also applicable to some industrial wastewaters which contain pollutants of a biodegradable nature. When the pollutants are hardly-biodegradable or toxic for the common biomass used in biological treatments, advanced oxidation processes may be an alternative to achieving the local final discharge limits [1-5]. The selection of the most appropriate method to be applied depends on a series of factors, the predominant of which are technical aspects such as the availability of facilities (equipment and vessels) and reagents (prices and providers), the volume to be treated, the physiochemical properties at the inlet of the process and the concentration of the primary pollutants. In this field, electrochemical oxidations have been proven to be applicable for water with low concentration of dissolved pollutants where incineration or chemical oxidation/reduction is not economically feasible. Electrochemical oxidation may be implemented in a compact form; it does not produce sludge and has no need of dissolved oxygen, acidity adjustment or the addition of any chemical reagent, and it has been found to be particularly useful when the wastewater has sufficient electrical conductivity (presence of dissolved salts). In practice, electrochemical oxidation works at ambient pressure and temperature, is apt for automation but requires a particular reactor design to work in optimized mass transfer conditions [6].

Electrochemical oxidation includes direct and indirect paths. In the first process strong oxidants are generated from the dissociative adsorption of water over polarized anodic surfaces: superior oxides $\mathrm{MO}_{\mathrm{x}+1}$ in the case of conductive metal oxide anodes, and hydroxyl radicals $\mathrm{OH}^{*}$ in the case of semiconductor like anodes. The organic molecules then react with these oxidants at the electrode surface. In indirect or mediated electrooxidation the abatement kinetics are generally enhanced by the occurrence of homogeneous oxidation pathways supported by oxidizing species (persulphates, hydrogen peroxide, etc.) which are generated over the anode and are dissolved into the solution. Particularly, in the presence of chloride ions, which are 
Table 1 Concentration of pharmaceuticals in wastewater [11]

\begin{tabular}{|c|c|}
\hline Pharmaceuticals & Name and concentrations \\
\hline Antibiotics & $\begin{array}{l}\text { Sulfonamides: sulfamethoxazole }(20-580 \mathrm{ng} / \mathrm{L}) \text {, Fluoroquinolones: ofloxacin }(6-52 \mathrm{ng} / \mathrm{L}) \text {, } \\
\text { ciprofloxacin }(6-60 \mathrm{ng} / \mathrm{L}) \text {, Bacteriostatic agents: trimethoprim }(110-370 \mathrm{ng} / \mathrm{L}) \text {, Penicillins: } \\
\text { penicillin } \mathrm{G}(<25 \mathrm{ng} / \mathrm{L})\end{array}$ \\
\hline $\begin{array}{l}\text { Analgesics, non-steroidal antipyretics } \\
\text { and anti-inflammatory }\end{array}$ & $\begin{array}{l}\text { Diclofenac }(10-510000 \mu \mathrm{g} / \mathrm{L}) \text {, naproxen }(500-7840 \mathrm{ng} / \mathrm{L}) \text {, ibuprofen }(490-990000 \mathrm{ng} / \mathrm{L}) \text {, } \\
\text { ketoprofen }(130-3000 \mathrm{ng} / \mathrm{L}) \text { y carbamazepine }(100-1680 \mathrm{ng} / \mathrm{L})\end{array}$ \\
\hline $\begin{array}{l}\text { Antiepileptics and stimulants (central } \\
\text { nervous systems) }\end{array}$ & Caffeine (3200-11440 ng/L) \\
\hline Beta blockers and triglycerides & $\begin{array}{l}\text { Propranolol (50 ng/L), atenolol (10-730 ng/L), metoprolol (10-390 ng/L), clofibric acid } \\
(470-170000 \mathrm{ng} / \mathrm{L}) \text {,gemfibrozil (300-3000 ng/L), Bezafibrate }(100-7600 \mathrm{ng} / \mathrm{L})\end{array}$ \\
\hline Steroid hormones & $17 \alpha$-ethynylestradiol ( $1 \mathrm{ng} / \mathrm{L}$ ), estrone, $17 \beta$-estradiol, estriol (usually $<10 \mathrm{ng} / \mathrm{L}$ ) \\
\hline Iodinated $\mathrm{X}$ rays contrast & Iopromida (26-7500 ng/L), iomeprol (1600 ng/L) \\
\hline Antiulcer & Ranitidine $(50-188 \mathrm{ng} / \mathrm{L})$ \\
\hline
\end{tabular}

very frequent in wastewaters, the generation of hypochlorous ions is rather easy. The presence of $\mathrm{Cl}$ ions lead to the oxidation of organic molecules to chloro-organic compounds, whose discharge limits in surface water basins are often even more restrictive than those of the original pollutant molecules [6].

In this work wastewater with dissolved pharmaceutical compounds was considered as effluent for which electrochemical oxidation may be a recommendable remediation technique [8-10].

Pharmaceuticals are physiologically designed to affect humans in trace concentrations, and as such they are found in very low concentrations in wastewater. However, their low biodegradability means they retain their chemical structure, leading to an accumulation in the environment and causing irreversible changes to the human genome, as well as effects on the endocrine system [11]. Table 1 classifies the groups of pharmaceuticals that are commonly found in wastewater and their respective concentrations [11].

In this work we propose an innovative electrochemical reactor based on a porous mass of semiconductor material which is placed between the anode and cathode. This reactor is fed with the current in continuous voltage mode and the porous mass becomes charged and acts as a bipolar electrode. In this electrochemical reactor the electrolysis current $(I)$, which crosses the central compartment, is comprised of an ionic current $\left(i_{i}\right)$ passing through the electrolyte and an electronic current $\left(i_{e}\right)$ passing through the porous mass. In porous bipolar electrodes the contribution of the latter current is generally of low intensity and only sufficient to compensate the de-polarization action of the environment [13]. The current in semiconductor materials is due to migration of generated positive "holes" $\left(\mathrm{h}^{+}\right)$at the valence band and electrons (e $\left.\mathrm{e}^{-}\right)$in the conduction band. Both current carriers can modify the polarization of the water molecules that dissociate into radicals [15], which can eventually react with dissolved organics or generate secondary oxidizing agents.
In a prior work [16] a batch mode of this reactor was tested for the generation of hydroxyl radicals by heterogeneous catalytic reaction between a "charged" semiconductor-surface and water dipoles, avoiding the generation of hypochlorous ions to find an application for the degradation of non-biodegradable toxic organic compounds.

The present research aims to evaluate the performance of specific energy consumption for a given reduction of toxic organic compound load in a continuous flow bipolar packedbed electrochemical reactor and to compare this with a classical parallel plate reactor. Diclofenac has been used in this work as a target pharmaceutical molecule due to its abundance and refractoriness. Table 2 [11] shows that diclofenac has a fairly low percentage removal by conventional oxidation methods (i.e. Fenton, photochemical, chlorination, ozonation methods).

Table 2 Pharmaceuticals concentrations detected (by liquid/mass chromatography) in waste water and influent treatment plants [11]

\begin{tabular}{llll}
\hline Therapeutic group & Compound & $\begin{array}{l}\text { Influent } \\
(\mathrm{ng} / \mathrm{L})\end{array}$ & $\begin{array}{l}\text { Effluent } \\
(\mathrm{ng} / \mathrm{L})\end{array}$ \\
\hline & Ketoprofen & 451 & 318 \\
Analgesic and & Naprxeno & 99 & 108 \\
anti- inflammatory & Ibuprofen & 516 & 266 \\
& Diclofenac & 250 & 215 \\
& Acetaminophen & 10194 & 2102 \\
\hline Lipid-lowering drugs & Clofibric acid & 72 & 28 \\
& Gemfibrozil & 155 & 120 \\
\hline Antiepileptic & Carbamazepine & 420 & 410 \\
\hline Antiulcer drugs & Ranitidine & 188 & 135 \\
\hline & Atenolol & 400 & 395 \\
B-blockers & Sotalol & 185 & 167 \\
& Propranolol & 290 & 168 \\
\hline
\end{tabular}




\section{Materials and Methods}

\subsection{Analytical method}

The residual concentration of diclofenac was analyzed during the electro-oxidation runs by means of UV-visible Beckman $\mathrm{Du}^{\circledR} 650$ USA spectrophotometry on periodically withdrawn samples. Measurement of carbon oxygen demand (COD) (on an Orbeco-Hellige water analysis system model 975-MP) was performed by the standard digestion method.

\subsection{Bipolar reactor configuration}

The bipolar packed-bed electrochemical reactor used in this study is shown in Fig. 1. It is composed of 3 tubular sections made of acrylic bonded by flanges of the same material, between which rubber discs are inserted to prevent liquid leakage. The total height of the reactor is $47 \mathrm{~cm}$; it is $4.5 \mathrm{~mm}$ thick and has an external diameter of $80 \mathrm{~mm}$.

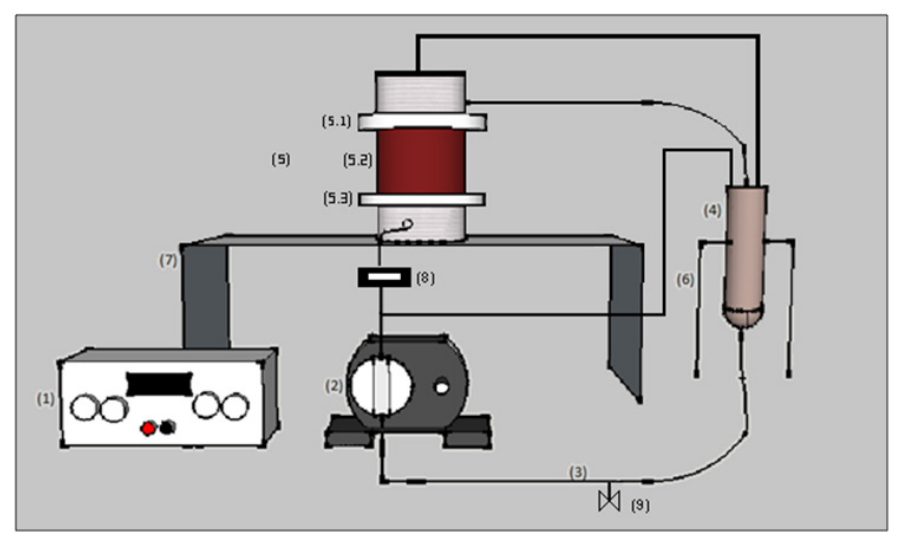

Fig. 1 Bipolar packed-bed electrochemical reactor. (1) Power source (2) centrifugal pump (3) hoses (4) recirculating tank (5) reactor (5.1) cathode chamber (5.2) central compartment (5.3) anode chamber (6) pedestal (7) support (8) flowmeter (9) valve.

The electric field was imposed by connecting the positive terminal of the high voltage power supply (FUG (Germany); operational ranges: $0-6 \mathrm{kV} ; 0-20 \mathrm{~mA}$ ) to the anode wire located at the bottom of the column, and the counter electrode (stainless steel) in the upper position of the intermediate section. The treatment solution was circulated between the cell and a container by a 0.5 H.P. centrifugal pump with a maximum flow-rate of $40 \mathrm{~L} \mathrm{~min}^{-1}$. The hydraulic circuit is completed with valves and turbine (magnetic) flow meters.

\subsection{Electrodes in the bipolar reactor}

The anode was titanium wire of 99\% purity (Aldrich) and the cathode used was a stainless steel mesh. These electrode materials were selected for their stability in the media considered. Furthermore, a semiconductor electrode of a porous mass of titanium oxide doped with antimony oxide was incorporated between the cathode and the anode. This titanium porous mass was obtained by means of a thermal treatment of titanium sponges (2-12 $\mathrm{mm}$ average particle diameter and $99.5 \%$ purity from Sigma) characterized by high micro-porosity (50\%). The pore diameter distribution $(200-1000 \mu \mathrm{m})$ exceeds the limiting diffusion layer thickness and promotes good mass transfer and continuous ionic diffusion within the mass. The optimal thermal treatment for the generation of surface titanium oxide was found to be $5 \mathrm{~h}$ at $500{ }^{\circ} \mathrm{C}$ under slight air flow. XRD analysis confirmed the formation of a thin and highly crystalline anatase layer.

\subsection{Bipolar reactor operation}

The starting volume for each run was $13 \mathrm{~L}$ of a solution of $1 \mathrm{~g} \mathrm{~L}^{-1}$ diclofenac $98 \%$ (Aldrich) containing $1 \mathrm{~g} \mathrm{~L}^{-1}$ of sodium sulfate (Merck $\mathrm{Na}_{2} \mathrm{SO}_{4} * 10 \mathrm{H}_{2} \mathrm{O}, 99 \%$ purity). Prior to feeding the reactor, the solution was completely homogenized. The principal parameters varied during the runs were: electrolyte concentration, flow rate, the distance between the electrodes and imposed electrical voltage.

\subsection{Parallel plate reactor configuration}

The parallel plate reactor shown in Fig. 2 was made of glass fiber and consisted of four flat electrodes; two anodes placed in the central position and two cathodes in the external zone. All plates were separated by $1 \mathrm{~cm}$ and measure $60 \mathrm{~cm}$ by $15 \mathrm{~cm}$. The cathode material was stainless steel and the anodes were made of oxidized titanium. The circuit consists of PVC pipes of $1 / 2$ inch; the liquid was re-circulated by a centrifugal pump ( $0.5 \mathrm{HP})$ and controlled by a (magnetic) turbine flow meter.

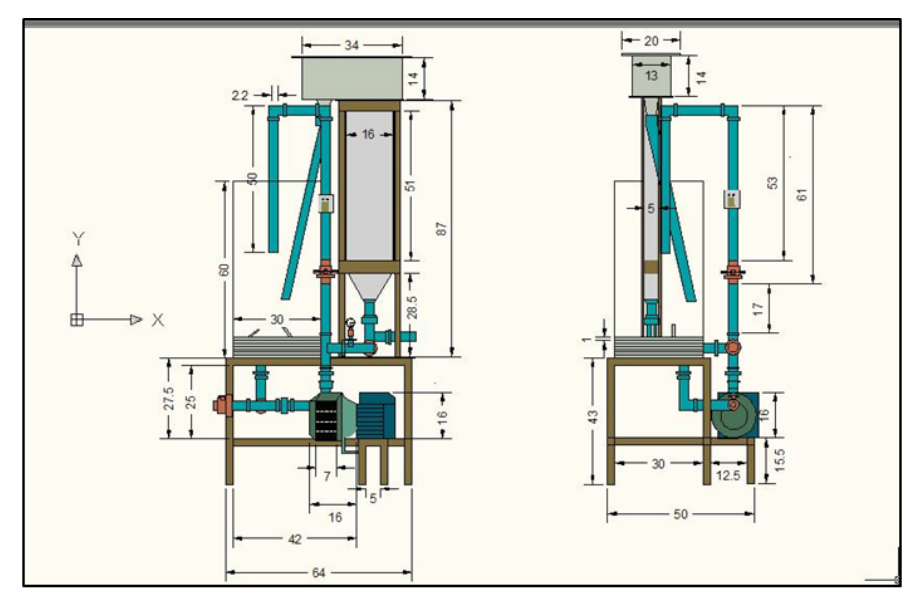

Fig. 2 Front and left view of parallel plate reactor. Dimensions are in centimetres.

The pump recycled the diclofenac solution from a plastic container $(18 \mathrm{~L})$ and sent it to the reactor $\left(3825 \mathrm{~cm}^{3}\right)$, where it was degraded. The initial concentration of diclofenac was 100 $\mathrm{mg} \mathrm{l}^{-1}$. In this case the reactor was operated in galvanostatic mode, i.e., with fixed current control.

\section{Results and discussion}

\subsection{Bipolar packed bed electrochemical reactor}

The electrolysis runs were performed and samples were collected regularly for analysis, recording the residual concentration ratio of $\mathrm{C}_{\mathrm{a} 0} / \mathrm{C}_{\mathrm{a}}$, where $\mathrm{C}_{\mathrm{a} 0}$ is the initial concentration and $\mathrm{C}_{\mathrm{a}}$ 
corresponds to concentration at time of sampling (measured by UV absorbance). The bipolar reactor was operated by varying salt concentrations at a fixed current intensity and the resultant behavior is shown in Fig. 3. This figure shows that work at a higher sodium sulfate concentration has a positive effect on degradation. In this case the voltage level is in the low range and, as expected, the higher salt content lowers the cell potential, thus resulting in a decrease in energy consumption. For the sodium sulfate content of $0.1 \mathrm{~g} \mathrm{~L}^{-1}$ the resultant cell potential is $10.5 \mathrm{~V}$, while for $1 \mathrm{~g} \mathrm{~L}^{-1}$ the cell potential drops to $6.5 \mathrm{~V}$. After two hours of operation the energy consumption for the experiment with $0.1 \mathrm{~g} \mathrm{~L}^{-1}$ of sodium sulfate was $270 \mathrm{~kJ}$, whereas for the experiment conducted at $1 \mathrm{~g} \mathrm{~L}^{-1}$ of sodium sulfate the energy consumption was $150 \mathrm{~kJ}$. Table 3 presents a summary of estimated first-order kinetic constants together with the calculated time for $90 \%$ abatement. In this voltage range the dissolved salt allows lesser current dissipation (joule effect) leading to improved current efficiency. It is also possible to hypothesize that the generation of persulphates may participate in the degradation of organic matter and thus the kinetics constant would then depend on current intensity or even increasing the migration of species.

Table 3 Summary of the results obtained at a distance of $14 \mathrm{~cm}$ between electrodes. Starting concentration of diclofenac equal $100 \mathrm{ppm}$.

\begin{tabular}{lll}
\hline Run & 1 & 2 \\
\hline $\mathrm{Na}_{2} \mathrm{SO}_{4}\left(\mathrm{~g} \mathrm{~L}^{-1}\right)$ & 0.1 & 1 \\
Flow rate $\left(\mathrm{L} \mathrm{min}^{-1}\right)$ & 1.14 & 1.14 \\
Potential $(\mathrm{V})$ & 10.5 & 6.5 \\
Kinetic contants $\left(\mathrm{h}^{-1}\right)$ & 0.006 & 0.036 \\
Time $(90 \%$ removal $)(\mathrm{h})$ & 383.76 & 63.96 \\
Energy consumption $\left(\mathrm{kWh} \mathrm{m}^{-3}\right)$ & 967.07 & 9.77 \\
\hline
\end{tabular}

The results shown in Fig. 4 suggest that increasing the flow rate does not generate a significant increase in the oxidation of diclofenac. It may therefore be inferred that the removal of the pharmaceutical is independent of the flow rate in these conditions; this may be due to an absence of limitations to diffusion when using the porous bed.

Comparing these results with those shown in Table 3 , it can be seen that increasing the distance between the electrodes raises the operative cell potential and, for a salt content of $1 \mathrm{~g} \mathrm{~L}^{-1}$, working with a lower current input leads to improved results in terms of both the apparent kinetics constant and the specific energy consumption, as summarized in Table 4. These results suggest the effective uses of the central porous mass as an active oxidizer, as the kinetics are not directly related to the current intensity induced under the imposed electric field. Energy consumption after $120 \mathrm{~min}$ was $27 \mathrm{~kJ}$, for all experiments.

The Fig. 5 shows that a decrease in current causes an increase in the voltage. The best results, in terms of apparent kinetics constant, were obtained without sodium sulfate and $20 \mathrm{~mA}$ (Table 5); however, the best economic conditions are obtained at the lowest obtained cell potential.

Fig. 6 shows that increasing the distance between electrodes (to $46 \mathrm{~cm}$ ) causes an expectable rise in cell potential and a positive effect on the apparent kinetics constant (Table 6).

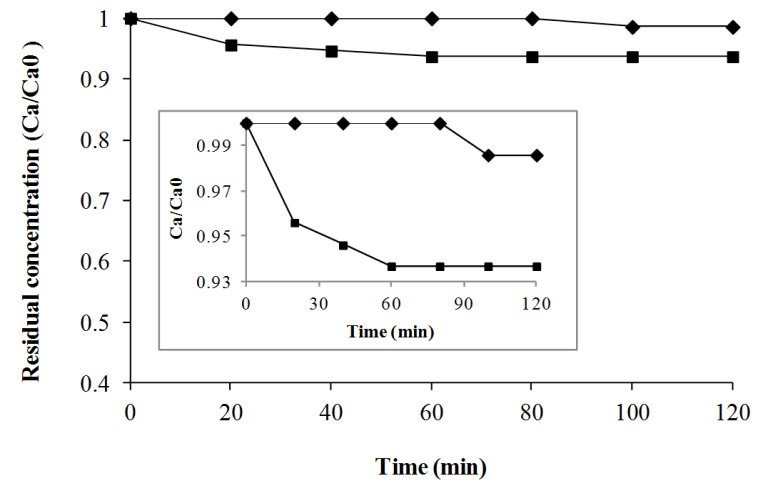

Fig. 3 Evolution of residual diclofenac concentration in a bipolar packed-bed electrochemical reactor. Flow rate: $1.14 \mathrm{~L} \mathrm{~min}^{-1}$; (diamonds) $\mathrm{Na}_{2} \mathrm{SO}_{4}=0.1 \mathrm{~g} \mathrm{~L}^{-1}$, (squares) $\mathrm{Na}_{2} \mathrm{SO}_{4}: 1 \mathrm{~g} \mathrm{~L}^{-1}$. Electrode separation $14 \mathrm{~cm}$. Insert: close-up of area of interest.

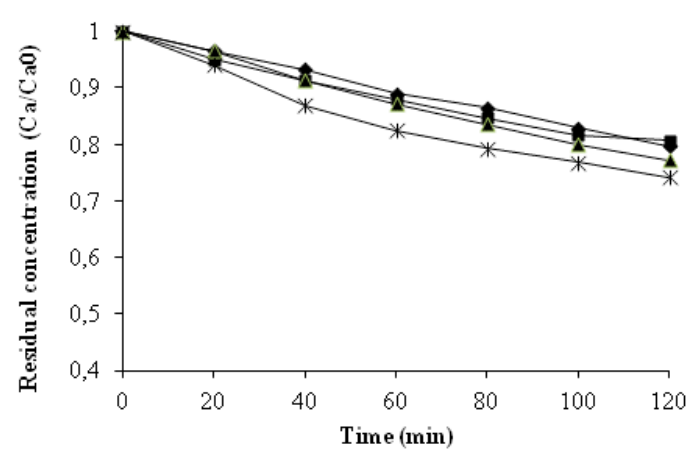

Fig. 4 Evolution of residual diclofenac concentration in a bipolar packed-bed electrochemical reactor. Initial diclofenac concentration: 100 ppm; Electrode separation: $32 \mathrm{~cm}$; imposed current: $0.1 \mathrm{~A}$; $\mathrm{Na}_{2} \mathrm{SO}_{4}$ concentration: $1 \mathrm{~g} \mathrm{~L}^{-1}$; voltage: $31 \mathrm{~V}$; Flow rate: $1.14 \mathrm{~L} \mathrm{~min}^{-1}$ (squares); Flow rate: $2.28 \mathrm{~L} \mathrm{~min}^{-1}$, (triangle); Flow rate: $4.56 \mathrm{~L} \mathrm{~min}^{-1}$ (circle); Flow rate: $9.35 \mathrm{~L} \mathrm{~min}^{-1}$ (asterisk)

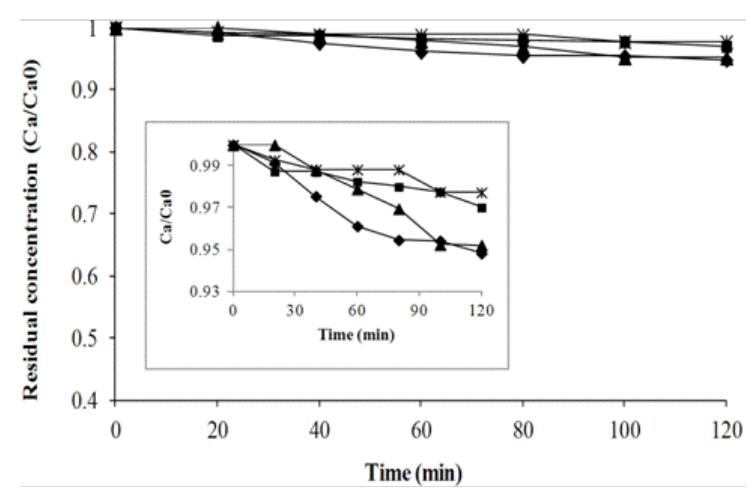

Fig. 5 Evolution of residual diclofenac concentration in a bipolar packed-bed electrochemical reactor. Initial diclofenac concentration: 100 ppm; Electrode separation: $32 \mathrm{~cm}$; Flow rate: $9.35 \mathrm{~L} \mathrm{~min}^{-1} ; \mathrm{Na}_{2} \mathrm{SO}_{4}$ concentration: $0 \mathrm{~g} \mathrm{~L}^{-1}$ (diamonds); $\mathrm{Na}_{2} \mathrm{SO}_{4}: 0.1 \mathrm{~g} \mathrm{~L}^{-1}$ (triangles); $\mathrm{Na}_{2} \mathrm{SO}_{4}: 1 \mathrm{~g} \mathrm{~L}^{-1}$ (asterisks). $\mathrm{Na}_{2} \mathrm{SO}_{4} 2 \mathrm{~g} \mathrm{~L}^{-1}$ (squares). Insert: close-up of area of interest . 


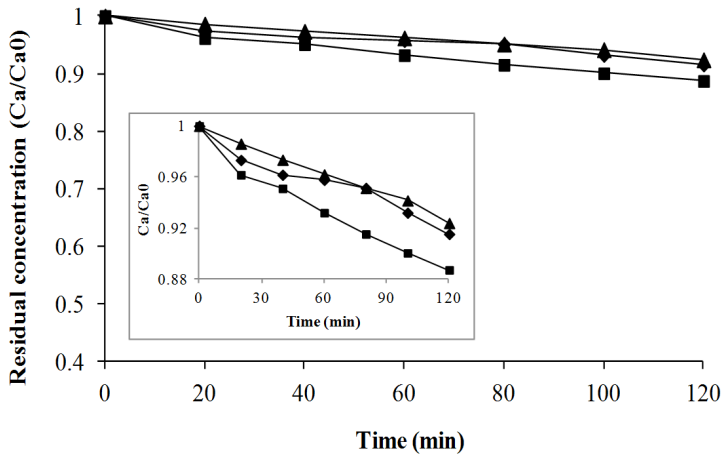

Fig. 6 Evolution of residual diclofenac concentration in a bipolar packed bed electrochemical reactor. Initial diclofenac concentration: 100 ppm; Electrode separation: $46 \mathrm{~cm}$; current: $20 \mathrm{~mA}$; Flow rate: $9.35 \mathrm{~L} \mathrm{~min}^{-1} ; \mathrm{Na}_{2} \mathrm{SO}_{4}: 0.1 \mathrm{~g} \mathrm{~L}^{-1}$ (diamonds); $\mathrm{Na}_{2} \mathrm{SO}_{4}: 1 \mathrm{~g} \mathrm{~L}^{-1}$ (squares); $\mathrm{Na}_{2} \mathrm{SO}_{4}: 0 \mathrm{~g} \mathrm{~L}^{-1}$ (triangle). Insert: close-up of area of interest.

Table 4 Summary of the results obtained at a distance of $32 \mathrm{~cm}$ between electrodes. Starting concentration of diclofenac equal $100 \mathrm{ppm} ; \mathrm{Na}_{2} \mathrm{SO}_{4}$ : $1 \mathrm{~g} \mathrm{~L}^{-1}$; current: $0.1 \mathrm{~A}$; voltage: $31 \mathrm{~V}$.

\begin{tabular}{lllll}
\hline Run & 1 & 2 & 3 & 4 \\
\hline Flow rate $\left(\mathrm{L} \mathrm{min}^{-1}\right)$ & 1.14 & 2.28 & 4.56 & 9.35 \\
Kinetic contants $\left(\mathrm{h}^{-1}\right)$ & 0.114 & 0.132 & 0.108 & 0.150 \\
Time $(90 \%$ removal$)(\mathrm{h})$ & 20.19 & 17.44 & 21.32 & 15.35 \\
Energy consumption $\left(\mathrm{kWh} \mathrm{m}^{-3}\right)$ & 4.81 & 4.15 & 8.08 & 3.66 \\
\hline
\end{tabular}

Table 5 Summary of the results obtained at a distance of $32 \mathrm{~cm}$ between electrodes. Starting concentration of diclofenac equal 100 ppm; current: $20 \mathrm{~mA}$ except the test done at $49 \mathrm{~V}$ which was done at $17.55 \mathrm{~mA}$; flow rate: $9.35 \mathrm{~L} \mathrm{~min}^{-1}$.

\begin{tabular}{lllll}
\hline Run & 1 & 2 & 3 & 4 \\
\hline $\mathrm{Na}_{2} \mathrm{SO}_{4}\left(\mathrm{~g} \mathrm{~L}^{-1}\right)$ & 0 & 0 & 0.1 & 0 \\
Potential (V) & 60 & 49 & 36 & 9 \\
Current (A) & 0.02 & 0.01755 & 0.02 & 0.02 \\
Kinetic contants $\left(\mathrm{h}^{-1}\right)$ & 0.03 & 0.012 & 0.03 & 0.012 \\
Time (90\% removal)(h) & 76.75 & 191.88 & 76.75 & 191.75 \\
Energy consumption $\left(\mathrm{kWh} \mathrm{m}^{-3}\right)$ & 7.08 & 12.69 & 4.25 & 2.65 \\
\hline
\end{tabular}

Table 6 Summary of the results obtained at a distance of $32 \mathrm{~cm}$ between electrodes. Starting concentration of diclofenac equal $100 \mathrm{ppm}$; current: 0.1A except the test done with $0.1 \mathrm{~g} \mathrm{~L}^{-1} \mathrm{de} \mathrm{Na}_{2} \mathrm{SO}_{4}$ which was done at $0.01 \mathrm{~A}$ : 9.35 $\mathrm{L} \mathrm{min}^{-1}$.

\begin{tabular}{llll}
\hline Run & 1 & 2 & 3 \\
\hline $\mathrm{Na}_{2} \mathrm{SO}_{4}\left(\mathrm{~g} \mathrm{~L}^{-1}\right)$ & 0.1 & 1 & 0 \\
Potential $(\mathrm{V})$ & 62 & 25 & 119 \\
Kinetic contants $\left(\mathrm{h}^{-1}\right)$ & 0.034 & 0.056 & 0.036 \\
Time $(90 \%$ removal$)(\mathrm{h})$ & 63.96 & 42.64 & 63.96 \\
Energy consumption $\left(\mathrm{kWh} \mathrm{m}^{-3}\right)$ & 6.10 & 1.60 & 11.70 \\
\hline
\end{tabular}

The comparison of the results obtained under different conditions indicates that there are optimum conditions of operation (near to a $1 \mathrm{~g} \mathrm{l}^{-1}$ of sulfate salt; $46 \mathrm{~cm}$ of inter-electrode gap) and it can be seen that to promote the reactivity of the semiconductor porous mass the cell potential must be as high as is attainable (limited by Ohm's law) and the best way to accomplish this is to increase the distance between the electrodes rather than diminishing the salt content.

\subsection{Parallel plate electrochemical reactor}

The more classical electrochemical reactor, the parallel plate reactor, was operated under galvanostatic conditions at constant salt content of $1 \mathrm{~g} \mathrm{~L}^{-1}$, varying the flow rate and imposed current. Fig. 7 shows that an increase in the flow rate favors the removal of diclofenac. The lowest energy consumption was $30 \mathrm{~kJ}$ obtained operating at a flow rate of $62 \mathrm{~L} \mathrm{~min}^{-1}$ and $2.4 \mathrm{~A}$ (resulting cell voltage of $4.2 \mathrm{~V}$ ).

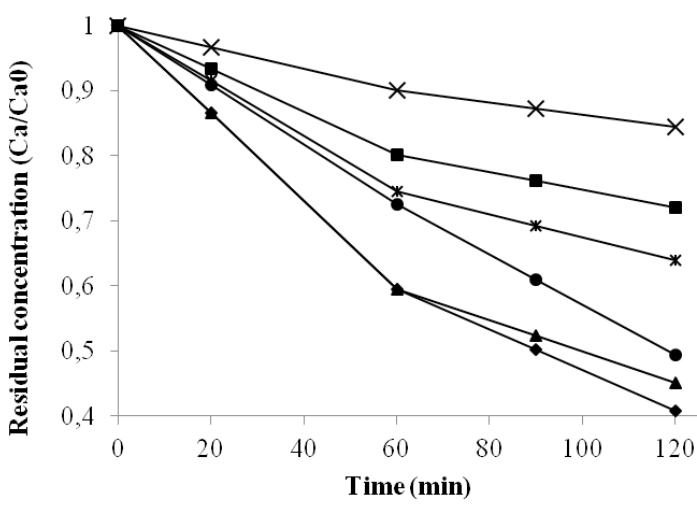

Fig. 7 Evolution of residual diclofenac concentration in a parallel plate electrochemical reactor. Initial diclofenac concentration: $100 \mathrm{ppm} ; \mathrm{Na}_{2} \mathrm{SO}_{4}$ :

$1 \mathrm{~g} \mathrm{~L}^{-1}$; flow rate: $62 \mathrm{~L} \mathrm{~min}^{-1}$ and current $2.4 \mathrm{~A}$ (diamonds); flow rate: $62 \mathrm{~L} \mathrm{~min}^{-1}$ and current $3.2 \mathrm{~A}$ (triangles); flow rate: $31 \mathrm{~L} \mathrm{~min}^{-1}$ and current $2.4 \mathrm{~A}$ (circles); flow rate: $31 \mathrm{~L} \mathrm{~min}^{-1}$ and current $3.2 \mathrm{~A}$ (asterisks); flow rate: $6 \mathrm{~L} \mathrm{~min}^{-1}$ and current $2.4 \mathrm{~A}$ (squares); flow rate: $6 \mathrm{~L} \mathrm{~min}^{-1}$ and current $3.2 \mathrm{~A}$ (crosses).

Fig. 8 shows that there is an optimum between the current and the removal rate, as the process is limited by diffusion of diclofenac to the anode and not by the reaction at the anode surface. The optimum condition must therefore be close to the diffusion limiting current.

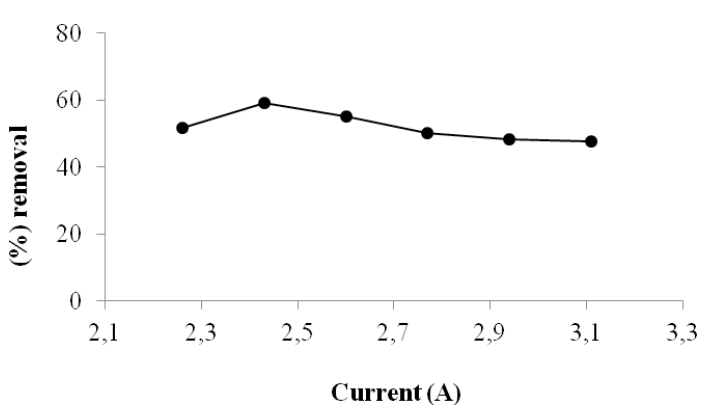

Fig. 8 Diclofenac removal versus applied current in a parallel plate electrochemical reactor. Flow rate $62 \mathrm{~L} \mathrm{~min}^{-1} ; \mathrm{Na}_{2} \mathrm{SO}_{4}$ concentration: $1 \mathrm{gL}^{-1}$

Table 7 summarizes all the results obtained in this reactor. 
Table 7 Summary of the results obtained in a parallel plate electrochemical reactor. Starting concentration of diclofenac equal $100 \mathrm{ppm}, \mathrm{Na}_{2} \mathrm{SO}_{4}=1 \mathrm{~g} \mathrm{~L}^{-1}$.

\begin{tabular}{llllll}
\hline Run & $\begin{array}{l}\text { Flow rate } \\
(\mathbf{L} / \mathbf{m i n})\end{array}$ & $\begin{array}{l}\text { Potential } \\
(\mathbf{V})\end{array}$ & $\begin{array}{l}\text { Current } \\
(\mathbf{A})\end{array}$ & $\begin{array}{l}\text { Time (90\% removal) } \\
(\mathbf{h})\end{array}$ & $\begin{array}{l}\text { Energy consumption } \\
\mathbf{k W h} / \mathbf{m}^{3}\end{array}$ \\
\hline 1 & 62 & 4.2 & 3.09 & 5.48 & 3.55 \\
2 & 6 & 4.3 & 3.2 & 12.79 & 8.79 \\
3 & 62 & 3.2 & 1.3 & 5.48 & 1.13 \\
4 & 6 & 3.3 & 1.3 & 38.37 & 8.23 \\
5 & 31 & 3.7 & 2.26 & 9.59 & 4.00 \\
6 & 31 & 3.8 & 2.26 & 6.39 & 2.74 \\
7 & 62 & 4.2 & 2.26 & 6.39 & 3.03 \\
8 & 62 & 4.3 & 2.43 & 5.48 & 2.86 \\
9 & 62 & 4.6 & 2.6 & 5.48 & 3.27 \\
10 & 62 & 4.1 & 2.77 & 6.39 & 3.62 \\
11 & 62 & 4.2 & 2.94 & 7.67 & 4.73 \\
12 & 62 & 4.7 & 3.11 & 7.67 & 5.60 \\
\hline
\end{tabular}

\subsection{Comparison between bipolar packed-bed electrochemical reactor and Parallel plate electrochemical reactor}

As possible to observe from the results, the kinetics of degradation is rather superior in the case of the parallel plate reactor which needs lower electrolysis time to reach higher degradation rate, however, a completely different scenario appear if the result were analyzed in terms of specific energy consumption.

The results obtained for Diclofenac oxidation in the two electrochemical reactors were compared in terms of specific energy consumption and are shown in Fig. 9. The calculations were made considering the experimentally determined kinetics and the energy consumption needed for the same abatement rate in both reactors modality. This comparative figure also includes the results of an analogous advanced oxidation process available in the literature [19]. In this comparison it can be seen that only the process comprising UV irradiation and the use of hydrogen peroxide (Photo-Fenton) presents energy costs that are comparable with the values determined in this study. An important consideration here is that the energy consumption reported using a PhotoFenton process is related to the UV lamp and does not consider the cost of the hydrogen peroxide (which is relatively high). With regard to the result obtained under the best conditions of the two electrochemical reactors it can be seen that the differences are negligible. Therefore, the use of the electrochemical reactor based on a bipolar electrode may be competitive with the classical parallel plate reactor only when operational conditions are appropriate to its use i.e. low level of salt content in the effluent or availability to generate high voltage and low electric current, or when there is a need to treat wastewater with a high level of chloride and to avoid chlorinated organic compound by-products, since with the porous semiconductor mass only hydroxyl radicals from dissociative adsorption of water occurs and the electrode potentials do not allow chlorine generation paths [17].

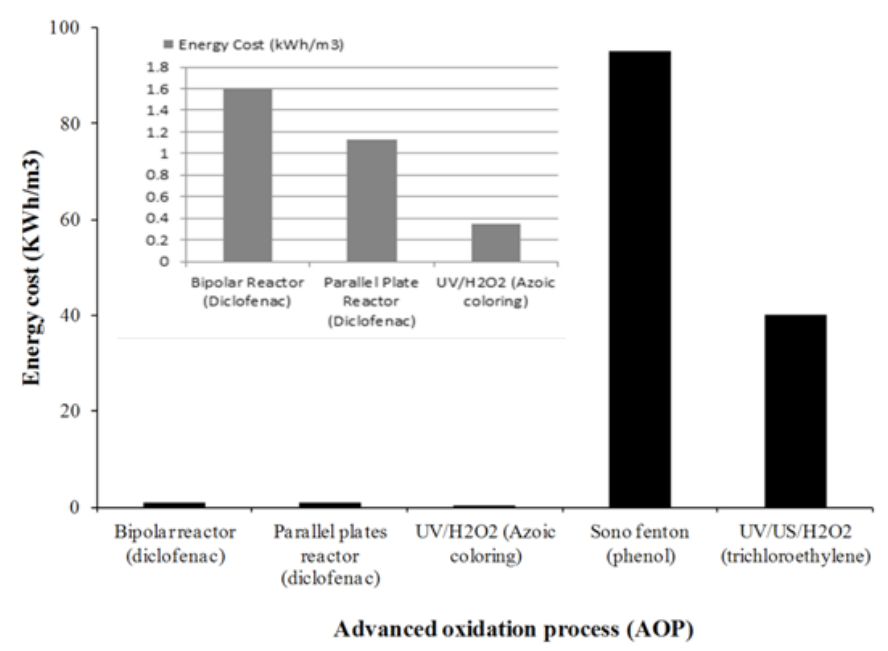

Fig. 9 Comparison of energy costs between electrochemical reactors and conventional oxidation processes [19]. Insert: close-up of the same results.

\section{Conclusions}

A novel electrochemical reactor was operated in continuous mode oxidizing dissolved pharmaceutical bio-refractory molecules (Diclofenac). The comparative results show that high cell potential attained with increased electrode distance favors the activity of the semiconductor porous mass placed between the electrodes. A solution of $100 \mathrm{mg} \mathrm{L}^{-1}$ of diclofenac is oxidized effectively with minimum specific energy consumption (under the best conditions tested) of $1.6 \mathrm{kWh} \mathrm{m}^{-3}$, which is comparable to the performance of other advanced oxidation processes. Similar results can be obtained using a parallel plate reactor (using the same electrode materials) however the two different reactor typology may answer different operative needs.

\section{Acknowledgement}

The financial support for this work from the "Vicerrectoria de Investigación PUCV" and Conicyt (Chile) (project Fondecyt $\left.\mathrm{N}^{\circ} 11070219\right)$ are gratefully acknowledged. 


\section{References}

[1] Almomani, F. A., Shawaqfah, M., Bhosale, R. R., Kumar, A. "Removal of emerging pharmaceuticals from wastewater by ozone-based advanced oxidation processes." Environmental Progress \& Sustainable Energy. 35(4), pp. 982-995. 2016.

https://doi.org/10.1002/ep.12306

[2] Zhang, S., Gitungo, S., Axe, L., Dyksen, J. E., Raczko, R. F. "A pilot plant study using conventional and advanced water treatment processes: Evaluating removal efficiency of indicator compounds representative of pharmaceuticals and personal care products." Water Research. 105, pp. 85-96. 2016.

https://doi.org/10.1016/j.watres.2016.08.033

[3] Jasim, S. Y., Saththasivam, J. "Advanced oxidation processes to remove cyanotoxins in water." Desalination. 406, pp. 83-87. 2017.

https://doi.org/10.1016/j.desal.2016.06.031

[4] Duan, X., He, X., Wang, D., Mezyk, S. P., Otto, S. C., Marfil-Vega, R., Mills, M. A., Dionysiou, D. D. "Decomposition of Iodinated Pharmaceuticals by UV-254 nm-assisted Advanced Oxidation Processes." Journal of Hazardous Materials. 323, pp. 489-499. 2017.

https://doi.org/10.1016/j.jhazmat.2016.04.022

[5] Klančar, A., Trontelj, J., Kristl, A., Meglič, A., Rozina, T., Justin, M. Z., Roškar, R. "An advanced oxidation process for wastewater treatment to reduce the ecological burden from pharmacotherapy and the agricultural use of pesticides." Ecological Engineering. 97, pp. 186-195. 2016. https://doi.org/10.1016/j.ecoleng.2016.09.010

[6] Sirés, I., Brillas, E. "Remediation of water pollution caused by pharmaceutical residues based on electrochemical separation and degradation technologies; a review." Environment International. 40, pp. 212-229. 2012. https://doi.org/10.1016/j.envint.2011.07.012

[7] Brillas, E., Boye, B., Sirés, I., Garrido, J. A., Rodríguez, R. M., Arias, C., Cabot, P.-L., Comminellis, Ch. "Electrochemical destruction of chlorophenoxy herbicides by anodic oxidation and electro-Fenton using a boron-doped diamond electrode." Electrochimica Acta. 49(25), pp. $4487-$ 4496. 2004.

https://doi.org/10.1016/j.electacta.2004.05.006

[8] Chatzitakis, A., Berberidou, C., Paspaltsis, I., Kyriakou, G., Sklaviadis, T., Poulios, I. "Photocatalytic degradation and drug activity reduction of chloramphenicol." Water Research. 42(1-2), pp. 386-394. 2008. https://doi.org/10.1016/j.watres.2007.07.030

[9] Mendez-Arriaga, F., Esplugas, S., Gimenez, J. "Photocatalytic degradation of non-steroidal anti-inflammatory drugs with $\mathrm{TiO} 2$ and simulated solar irradiation." Water Research. 42(3), pp. 585-594. 2008. https://doi.org/10.1016/j.watres.2007.08.002
[10] Carlesi Jara, C., Fino, D., Specchia, V., Saracco, G., Spinelli, P. "Electrochemical removal of antibiotics from wastewaters." Applied Catalysis B: Environmental. 70(1-4), pp. 479-487. 2007.

https://doi.org/10.1016/j.apcatb.2005.11.035

[11] Petrovic, M., Hernando, M. D., Díaz-Cruz, M. S., Barceló, D. "Liquid chromatography- tandem mass spectrometry for the analysis of pharmaceuticals residues in environmental samples." Journal of Chromatography A. 1067(1-2), pp. 1-14. 2005.

https://doi.org/10.1016/j.chroma.2004.10.110

[12] Al-Rifai, J. H., Gabelish, C. L., Schafer, A. I. "Occurrence of pharmaceutically active and non-steroidal estrogenic compounds in three different wastewater recycling schemes in Australia." Chemosphere. 69(5), pp. 803-815. 2007. https://doi.org/10.1016/j.chemosphere.2007.04.069

[13] Maja, M., Penazzi, N., Ginatta, M. V., Orsello, G. M. "An alkali metal bipolar electrode for molten salt electrolysis." Journal of Electrochemical Society. 137(11), pp. 3498-3504. 1990. https://doi.org/10.1149/1.2086256

[14] Maja, M., Spinelli, P. "A bipolar porous electrode with internal mass transfer for electrochemical reactors." Chemical Engineering Science. 47(9-11), pp. 2915-2920. 1992.

https://doi.org/10.1016/0009-2509(92)87151-F

[15] Klyachko, D.V., Rowntree, P., Sanche, L. "Dynamics of surface reactions induced by low- energy electrons oxidation of hydrogen-passivated Si by H2O." Surface Science. 389(1-3), pp. 29-47. 1997. https://doi.org/10.1016/S0039-6028(97)00354-3

[16] Carlesi Jara, C., Fino, D., Saracco, G., Specchia, V. "Three-compartment electro-oxidation reactor for bio-refractory organics degradation." Chemical Engineering Science. 62, pp 5644-5647. 2007.

https://doi.org/10.1016/j.ces.2007.02.003

[17] Carlesi Jara, C., Fino, D., Spinelli, P. "Bio-refractory organics degradation over semiconductor foam under a superimposed electric field." Catalysis Today. 124(3-4), pp. 273-279. 2007. https://doi.org/10.1016/j.cattod.2007.03.045

[18] Heberer, T., Reddersen, K., Mechlinski, A. "From municipal sewage to drinking water: Fate and removal of pharmaceuticals residues in the aquatic environment in urban areas." Water Science and Technology. 46(3), pp 81-88. 2002.

[19] Mahamuni, N.N., Adewuyi, Y. G. "Advanced oxidation processes (AOPs) involving ultrasound for waste water treatment: A review with emphasis on cost estimation." Ultrasonics Sonochemistry. 17(6), pp. 990-1003. 2010. https://doi.org/10.1016/j.ultsonch.2009.09.005 